\title{
Effect of straight dough X pre-fermented dough method on composite wheat breads characteristics
}

\author{
Raíssa Oliveira LUIZ1, Fernanda Maria. VANIN ${ }^{1 *}$
}

\begin{abstract}
Bread fermentation is one of the most important steps in breadmaking. In straight dough method fermentation stage is realized after dough mixing; while in pre-fermented method, part of ingredients is mixed and rested for some hours in order to preferment. This second method is well known to produce breads with improved properties, however no studies related to the production of composite bread using pre-fermented dough method can be found in the literature. Therefore, the objective of this study was to verify the effect of pre-fermented dough process method on a composite bread properties. Control breads (wheat bread) and green-banana-wheat bread were produced by straight and pre-fermented dough method. Breads were evaluated in relation to local water content, water loss, color parameters, specific volume, crumb porosity and texture profile analyses. Pre-fermented breads presented significantly higher specific volume in relation to straight breads. Similarly, pre-fermented method give breads with lower values of water loss, and lower levels of darkening. All of this could contributed to the better crumb texture properties of pre-fermented breads in relation to straight dough method. Therefore, it could be concluded that pre-fermentation dough method improved the technological properties of composite bread, representing an important strategy to be more explored.
\end{abstract}

Keywords: technological properties; texture; specific volume; water loss.

Practical Application: The results showed in this study will be useful for food industry as well as bakeries, and local entrepreneurs. Results showed that composite-wheat bread could be produced with more interesting results by using pre-fermented dough method process.

\section{Introduction}

Cereal fermentation is one of the oldest biotechnological processes used, once the production of bread and beer have been reported since primordial periods (Poutanen et al., 2009). For bread production, the dough fermentation has been made by allowing the dough be fermented naturally by the microorganisms present in the grains, during relatively longer times.

In order to reduce the period of bread production straight dough method has been the most simple and used breadmaking method (Delcour \& Hoseney, 2010). In this method all formula ingredients are mixed together, in order to develop the dough, and then rested, divided, fermented and finally baked. Most of bread researches papers used straight dough method (Alcântara et al., 2020b; Bárcenas et al., 2004; Bredariol et al., 2019; Carr et al., 2006; Datta et al., 2007; Purlis, 2010; Ureta et al., 2018; Wagner et al., 2008).

However, bread production has been also influenced by cultural differences. In North America the most predominant commercial breadmaking is the sponge dough method (Delcour \& Hoseney, 2010), or pre-fermented dough method, while in France sourdough breadmaking or "pain au levain" is largely produced. Both methods are characterized by longer fermentation times in relation to straight dough method, while sponge dough method has largely industrial use.
Pre-fermented dough method is characterized by a prefermentation step, where part of the flour, as well as part of the water and yeast are mixed, and the developed dough rest up to 5 hours, developing a sponge like structure (Delcour \& Hoseney, 2010). After this pre-fermentation period, the remaining ingredients are mixed into the "sponge" in order to produce the final dough. In general, sponge dough method produces bread with better aroma and flavor, higher volume, and better crumb texture properties (Delcour \& Hoseney, 2010; Katina et al., 2005; Poutanen et al., 2009). Furthermore, the process is more flexible, once the sponge can be fermented for longer times in order to accommodate process troubles, besides to accept more flour varieties, without larger variations in final bread properties and quality. Besides these aspects, the longer fermentation result in a more acidic dough, which has been shown to be very useful to improve the texture and palatability of products rich in fibers, and also the stabilization or improving the levels of bioactive compounds (Katina et al., 2005). Thus, the use of pre-fermented dough method could be an interesting strategy for bread production using composite flours. However, no comparative studies, or even using pre-fermented dough method, are available in the literature for the development of composite wheat bread. Furthermore, a scarce number of comparative studies published have focused in conventional wheat breads (Amr \& Ajo, 2005; 
Baasandorj et al., 2020; Gassenmeier \& Schieberle, 1995), instead of composite breads. Especially, no study has been performed to compare straight and pre-fermented dough method, i.e., combining different fermentation conditions, the evaluation of composite breads.

Different composite flours have been used for the production of composite wheat breads, as well as rice (Alcântara et al., 2020a; Sciarini et al., 2010; Tuncel et al., 2014), corn (Alcântara et al., 2020a; López et al., 2004; Gujral \& Pathak, 2002; Gularte \& Rosell, 2011), cassava (Shittu et al., 2007), and green-banana (Alcântara et al., 2020a, b; Ho et al., 2013, 2014). A recent study using different composite flours evaluated the effect of different flours and its concentration on local dough properties during bread baking and between the evaluated flours concluded that green banana flour represents one of the flours that most modify the dough properties (Alcântara et al., 2020a). Therefore, it could be supposed that green banana flour represents a key strategy to evaluate the effect of pre-fermented dough method on the development of composite wheat bread. Furthermore, if a considerable number of studies already reported the use the of green-banana flour for the development of composite wheat breads (Alcântara et al., 2020a, b; Aziah et al., 2012; Faisant et al., 1995; Juarez-Garcia et al., 2006), none of those studies evaluated the effect of dough method on final bread properties.

Therefore, the aim of this study was to evaluate the effect of pre-fermented dough process method on a composite bread properties using green banana and wheat flour Consequently, this study will allow predicting how the use of the pre-fermented method may or may not be useful in the production of composite breads.

\section{Material and methods}

\subsection{Materials}

Materials used were: wheat flour (Bunge Suprema, Brazil) (11.2 $\mathrm{g}$ of water/100 $\mathrm{g}$ flour, $14.7 \mathrm{~g}$ of protein/100 $\mathrm{g}$ dry matter (DM), $0.6 \mathrm{~g}$ of ash/100 g DM, $1.2 \mathrm{~g}$ of fat/100 g DM), green banana flour (Zona Cerealista, Brazil) (5.1 g of water/100 g flour, $7.8 \mathrm{~g}$ of protein/100 g dry matter (DM), $6.3 \mathrm{~g}$ of ash/100 $\mathrm{g}$ DM, $1.1 \mathrm{~g}$ of fat/100 g DM) salt (Cisne, Brazil), improver (S500 Puratos, Brazil, composed by a mix of corn starch xylanase, emulsifier polysorbate 80 and estearoil-2-lactil lactate to sodium, ascorbic acid, azodicarbonamide and $\alpha$-amylase) and fresh yeast (Fleischmann, Brazil), all them acquired on local commerce.

\subsection{Methods}

\section{Bread production}

\section{Straight dough method}

Straight dough bread was produced according to the methodology described by Bredariol et al., 2019), with some adaptations. Control breads were prepared using a dough formulation composed of wheat flour (1500 g), water (900 g), salt (30 g), fresh biological yeast (30 g), and improver (15 g). The ingredients were mixed (FAMAG Brazil), at low speed, for 18 minutes. After this, the dough was placed to rest for 10 minutes at room temperature and then divided into portions of $150 \mathrm{~g}$ and placed to rest for another 15 minutes. After the 15 minute period, the portions were modeled using a modeler (MP500, Prática, Brazil). Breads were then fermented (Klimaquip, brazil) at $35^{\circ} \mathrm{C}$ and $85 \%$ of relative humidity, until reaches 3.5 times its initial volume (approximately 1 hour). Breads were baked at $200{ }^{\circ} \mathrm{C}$ during 14 minutes. Breads produced with green banana flour were produced in a similar way, considering just that wheat flour was substituted by $10 \%$ of green banana flour. The concentration of green-banana flour was choose considering previous literature (Alcântara et al., 2020a, b; Aziah et al., 2012; Tribess et al., 2009). Bread formulations were produced in triplicate, and for each triplicate three different breads were taken for bread analyses properties.

\section{Pre-fermented dough method}

Pre-fermented dough method followed the methodology described by Gassenmeier \& Schieberle (1995) with some modifications. The sponge was prepared with wheat flour $(450 \mathrm{~g})$, water $(450 \mathrm{~g})$ and fresh biological yeast $(1.2 \mathrm{~g})$. This ingredients were mixed manually and then leave to rest for 24 hours at room temperature. After this fermentation, the sponge was added with the remaining wheat flour (1050 g), water (450 g), yeast (28.8 g), in addition to salt (30 g) and improver (15 g). The rest of the production followed the same methodology as the breads produced by the straight dough method. Again, breads produced with green banana flour were produced in a similar way, considering just that wheat flour was substituted by $10 \%$ of green banana flour. Similarly, bread formulations were produced in triplicate, and for each triplicate three different breads were taken for bread analyses properties.

\section{Bread characterization}

Water loss during baking and water content

Doughs were weighed before and after baking in order to determine the water loss during baking. The local water content for crumb and crust were also determined, from placing samples at $105^{\circ} \mathrm{C}$ for $24 \mathrm{~h}$ (Bredariol et al., 2019).

Volume and specific volume

One hour after the end of baking, the volume of the bread was evaluated using the VolScan equipment, and the specific volume was calculated by the ratio between the volume and the mass of the baked bread $\left(\mathrm{m}^{3} \cdot \mathrm{g}^{-1}\right)$ (Bárcenas \& Rosell, 2006).

\section{Crumb porosity}

The porosity of the bread crumb, at the end of the baking process (also after one hour), was evaluated using a digital image analysis system according to Crowley et al. (2000). Images of the central slice of the bread were captured using a Hewlett Packard flatbed scanner (HP ScanJet G4050, U.S.A.), and then scanned at a scale of 256 gray levels of 150 dots per inch (dpi). The alveolar parameters analyzed were: area $\left(\mathrm{mm}^{2}\right)$, average perimeter $(\mathrm{mm})$ and void fraction (\%). 


\section{Color parameters}

The color parameters chroma $\mathrm{a}^{*}$, chroma $\mathrm{b}^{*}$ and luminosity $\left(\mathrm{L}^{*}\right)$ of the bread crust were evaluated using a Miniscan XE colorimeter (HunterLab). To determine the parameters chroma $\mathrm{a}^{*}$, chroma $\mathrm{b}^{*}$ and $\mathrm{L}^{*}$ the reading was performed in triplicate. The total color difference $\left(\mathrm{E}^{*}\right)$ were calculated by the mean values of color parameters $\mathrm{L}^{*}, \mathrm{a}^{*}$ and $\mathrm{b}^{*}$, between the two dough methodologies used (Purlis \& Salvadori, 2007).

Texture profile analysis

At the end of the baking process, the texture parameters were determined through the texture profile analysis (TPA) of the crumb, using a TA-XT2i texturometer (Stable Microsystems, Surrey, UK) (P/25 probe) (Bárcenas \& Rosell, 2006). Through this analysis, the following parameters were determined: hardness, elasticity, cohesiveness, and chewiness.

\section{Statistical analyses}

Statistical analysis was performed using SAS software (Version 9.2, SAS, Inc.). Differences between means were determined by Duncan's test (95\% confidence interval).

\section{Results}

All produced breads presented visually good aspects. In general, straight dough presented visually more denser, thicker, with more difficulty to handle than that produced by pre-fermented method. Pre-fermented dough is mixed and fermented for longer time, which probably allowed a more hydrated and aerated dough in comparison to straight dough. It could be supposed that due to longer mixing and fermentation time gluten development could achieve greater levels of relaxation, which in turn enhanced dough extensibility.

In order to compare the results, control breads (produced with only wheat flour) were entitled wheat bread (WB), and breads with $10 \%$ of green banana flour and wheat flour, greenbanana-wheat bread (GBWB). Figure 1 present images of WB and GBWB produced by straight and pre-fermented dough method.

\subsection{Water content and water loss}

The water content of the different dough bread, just before baking, not showed any significant difference, either due to the difference in the production method used (straight or pre-fermented), and also due to the replacement of wheat flour by green banana flour (Table 1). Likewise, no significant difference in the crumb water content between the different breads evaluated were observed. On the other hand, the water content of bread crusts of GBWB were higher when compared to WB. No significant difference on the crumb water content of GBWT, independent on the dough methods used, was observed.

In relation to bread water loss during baking (Table 1), GBWB presented significantly lower water loss during baking in comparison to control breads (WB). In relation to bread method production, breads produced by straight method presented lower water loss during baking. This results are in agreement with those reported by Amr \& Ajo (2005). These authors producing flat bread with only wheat flour by straight and pre-fermented method, related significantly lower moisture content for breads produced by the straight method.

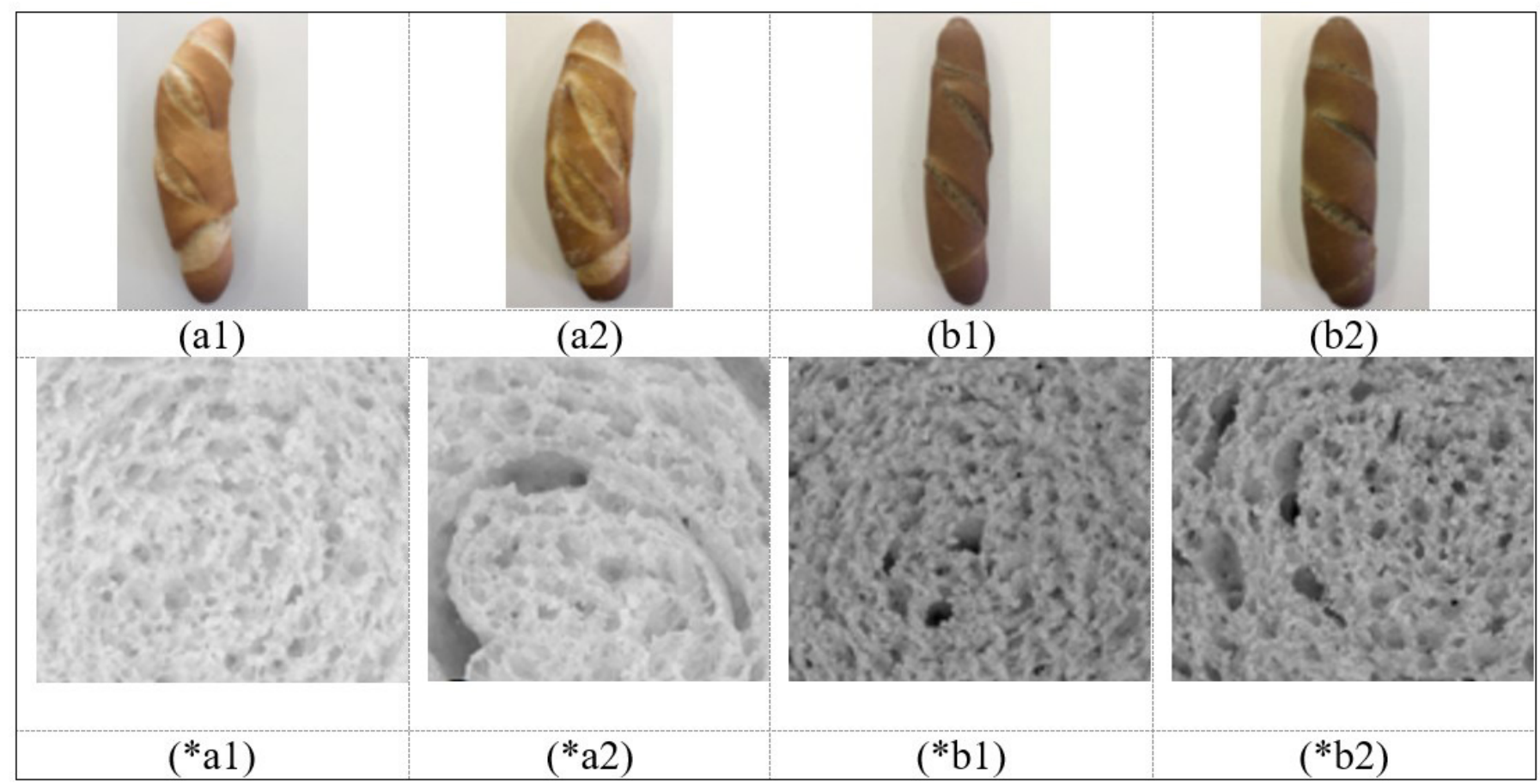

Figure 1. Photos and scanner $\left(^{\star}\right)$ images of breads produced: (a) wheat bread (control bread), (b) green-banana-wheat bread, using straight (1) or pre-fermented dough method (2). 


\subsection{Color parameters}

In general, dough production method not significantly affect crumb and crust color parameters of breads (Table 2). However, the $L^{\star}$, the luminosity of crumb and crust bread, significantly decreased when breads were produced by pre-fermented dough method. This result could be related to the higher water loss of these breads, as observed in Table 1. The total color difference $\left(E^{*}\right)$ calculated evidenced that crust color of control breads, made with only wheat flour, were higher affected by dough production method, in comparison to green banana breads. For crumb, $E^{\star}$ calculated for both bread types were, in general, similar. Baasandorj et al. (2020) observed no variation in color parameters of flat breads produced by the same the methods. No other studies were found in the literature for color bread observation in function of different dough methods of production. Besides, GBWB presented lower values of $\mathrm{L}^{*}$, which could be related to the brown color of green banana flour.

\subsection{Specific volume}

In relation to the specific volume (Figure 2), as expected the substitution of wheat flour by $10 \%$ of green banana flour resulted in a significant reduction of the specific volume compared to the control bread (WB). However, when GBWB were produced by pre-fermented method the specific volume was significantly higher when compared to these produced by straight dough method. Similarly, for WB a significant higher specific volume compared to breads produced by direct method was also verified.

Baasandorj et al. (2020) and Amr \& Ajo (2005) also observed higher specific volume for WB produced by pre-fermented dough (or sponge dough).

In WB the gluten network, composed by gliadin and glutenin protein, contribute to the viscosity and elasticity of the dough, which in turn favorize the gas retention produced by the yeast, resulting in a bread with greater volume. GBWB probably have a weaker gluten network, since in this case gluten network could be fragmented by green banana flour components, and consequently, a lower volume is observed. However, the breads produced by pre-fermented dough method had significantly higher specific volume than those produced by straight dough method. Therefore, it could be supposed that pre-fermentation step may have favored the stability of the gluten network, even being weaker when compared to WB.

\subsection{Crumb porosity}

Table 3 present the results of bread crumb porosity. A higher average area was observed for WB in comparison with GBWB. This result is agreement with those reported by Alcântara et al. (2020a) for breads produced with green-banana and wheat flour also. Average perimeter and void fraction not presented significantly effect in function of the different dough method of production or flours used in bread production.

The void fraction is equivalent to the gas cells present in the bread crumb. However, it is not possible to state the size of the cell present in the crumb, since only a portion of the sliced

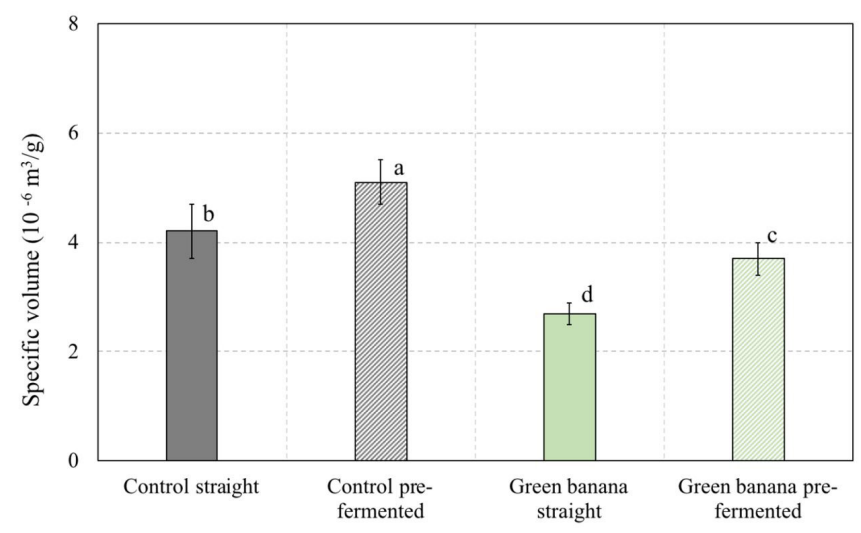

Figure 2. Specific volume of breads produced with wheat flour and green banana and wheat flour using straight or pre-fermented dough method. ${ }^{\star}$ Different lower case letters indicate a significant difference $(\mathrm{p}<0.05)$ between the means for the different breads evaluated.

Table 1. Local water content and water loss of the different breads evaluated.

\begin{tabular}{lcccc}
\hline \multicolumn{1}{c}{ Bread } & Dough (\%) & Crumb (\%) & Crust (\%) & Water loss (\%) \\
\hline Control bread-straight & $44.8 \pm 0.5^{\mathrm{a}}$ & $44.37 \pm 1.4^{\mathrm{a}}$ & $11.7 \pm 0.4^{\mathrm{a}}$ & $18.0 \pm 1.1^{\mathrm{b}}$ \\
Control bread-pre-fermented & $44.8 \pm 0.7^{\mathrm{a}}$ & $45.50 \pm 0.9^{\mathrm{a}}$ & $11.9 \pm 1.1^{\mathrm{a}}$ & $19.6 \pm 1.1^{\mathrm{a}}$ \\
Green banana-straight & $44.8 \pm 0.4^{\mathrm{a}}$ & $45.05 \pm 1.3^{\mathrm{a}}$ & $13.9 \pm 1.1^{\mathrm{b}}$ & $15.4 \pm 0.7^{\mathrm{d}}$ \\
Green banana-pre-fermented & $44.5 \pm 0.9^{\mathrm{a}}$ & $44.78 \pm 1.1^{\mathrm{a}}$ & $14.6 \pm 0.9^{\mathrm{b}}$ & $16.7 \pm 1.2^{\mathrm{c}}$ \\
\hline
\end{tabular}

${ }^{\star}$ Different lower case letters in the same column indicate a significant difference $(\mathrm{p}<0.05)$ between the means for the different breads evaluated.

Table 2. Color parameter of the crumb and crust of the different breads evaluated.

\begin{tabular}{|c|c|c|c|c|c|c|}
\hline \multirow{2}{*}{ Bread } & \multicolumn{3}{|c|}{ Crumb } & \multicolumn{3}{|c|}{ Crust } \\
\hline & $\mathrm{L}^{*}$ & $\mathrm{a}^{*}$ & $\mathrm{~b}^{*}$ & $\mathrm{~L}^{*}$ & $\mathrm{a}^{*}$ & $\mathrm{~b}^{*}$ \\
\hline Control bread-straight & $80.2 \pm 0.3^{\mathrm{d}}$ & $2.4 \pm 0.2^{\mathrm{a}}$ & $21.0 \pm 0.3^{c}$ & $65.1 \pm 0.3^{\mathrm{d}}$ & $16.1 \pm 0.4^{\mathrm{b}}$ & $32.6 \pm 0.4$ \\
\hline Control bread-pre-fermented & $78.6 \pm 0.8^{c}$ & $2.3 \pm 0.2^{\mathrm{a}}$ & $19.9 \pm 0.4^{\mathrm{b}}$ & $60.5 \pm 0.5^{c}$ & $17.0 \pm 0.4^{\mathrm{b}}$ & $30.9 \pm 0.5$ \\
\hline $\mathrm{E}^{\star}$ & & 1.92 & & & 4.98 & \\
\hline Green banana-straight & $52.1 \pm 0.5^{\mathrm{b}}$ & $4.4 \pm 0.1^{\mathrm{b}}$ & $16.3 \pm 0.2^{\mathrm{a}}$ & $54.5 \pm 2.3^{\mathrm{b}}$ & $11.9 \pm 1.3^{\mathrm{a}}$ & $24.9 \pm 1.8^{b}$ \\
\hline Green banana-pre-fermented & $49.8 \pm 0.3^{\mathrm{a}}$ & $4.3 \pm 0.2^{\mathrm{b}}$ & $16.2 \pm 0.4^{\mathrm{a}}$ & $51.6 \pm 0.7^{\mathrm{a}}$ & $11.6 \pm 0.4^{\mathrm{a}}$ & $22.9 \pm 0.5^{a}$ \\
\hline $\mathrm{E}^{*}$ & & 2.23 & & & 3.54 & \\
\hline
\end{tabular}

\footnotetext{
${ }^{\star}$ Different lower case letters indicate in the same column a significant difference $(\mathrm{p}<0.05)$ between the means for the different breads evaluated.
} 
bread has been binarized for analysis and, as a result, larger cells are more likely to be cut from this image than smaller cell (Crowley et al., 2000). Examples of crumb images of the different breads produced are presented in Figure 1. In accordance with baking test results, significant differences could be observed between the crumb grain from the different bread, WB and GBWB, and dough method, straight and pre-fermented. WB presented higher and more uniform cell than GBWF, which presented same larger cells and heterogeneity. The occurrence of larger cells in breads produced by pre-fermented dough method can be explained by the fact that they present a thicker and harder crust than breads produced by the straight method, capable to retain more the gases during fermentation stage. Therefore, it could be supposed that the denser and harder crust of breads produced by pre-fermented dough method, difficult the gas the lost which in turn accumulated at the crumb, favorizing consequently bigger and non-uniform cell as observed in prefermented crumb images (Figure 1).

\subsection{Texture profile analyses}

Results of texture profile analyses were presented in Figure 3. In general, control breads not presented significantly difference for hardness(Figure 3a), elasticity (Figure 3b), cohesiveness (Figure $3 \mathrm{c}$ ) and chewiness (Figure 3d) in function of dough method production. Furthermore, the results obtained for control breads were similar to those presented in the literature for breads produced with only wheat flour (Bredariol et al., 2019; Özkaya et al., 2018). At another hand, Różyło (2013) evaluating the dough method production, observed lower values for hardness and chewiness of breads produced by pre-fermented dough method, in comparison with straight dough method. This differences could be related to wheat flour protein quality (Baasandorj et al., 2020). In general, wheat flour from Brazil, applied in this study, presented lower quality in comparison to flour produced in north hemisphere.

Table 3. Average area, average perimeter and void fraction of bread produced with wheat flour and green banana and wheat flour using straight or pre-fermented dough method.

\begin{tabular}{lccc}
\hline \multicolumn{1}{c}{ Bread } & Average area $\left(\mathrm{mm}^{2}\right)$ & Average perimeter $(\mathrm{mm})$ & Void fraction $(\%)$ \\
\hline Control bread-straight & $0.60 \pm 0.07^{\mathrm{b}}$ & $2.7 \pm 1.0^{\mathrm{a}}$ & $30.75 \pm 3.1^{\mathrm{a}}$ \\
Control bread-pre-fermented & $0.61 \pm 0.08^{\mathrm{b}}$ & $2.1 \pm 0.1^{\mathrm{a}}$ & $30.93 \pm 2.8^{\mathrm{a}}$ \\
Green banana-straight & $0.49 \pm 0.09^{\mathrm{a}}$ & $2.5 \pm 0.7^{\mathrm{a}}$ & $30.96 \pm 1.7^{\mathrm{a}}$ \\
Green banana-pre-fermented & $0.47 \pm 0.08^{\mathrm{a}}$ & $2.0 \pm 0.2^{\mathrm{a}}$ & $32.24 \pm 1.7^{\mathrm{a}}$ \\
\hline
\end{tabular}

${ }^{\star}$ Different lower case letters in the same column indicate a significant difference $(\mathrm{p}<0.05)$ between the means for the different breads evaluated.

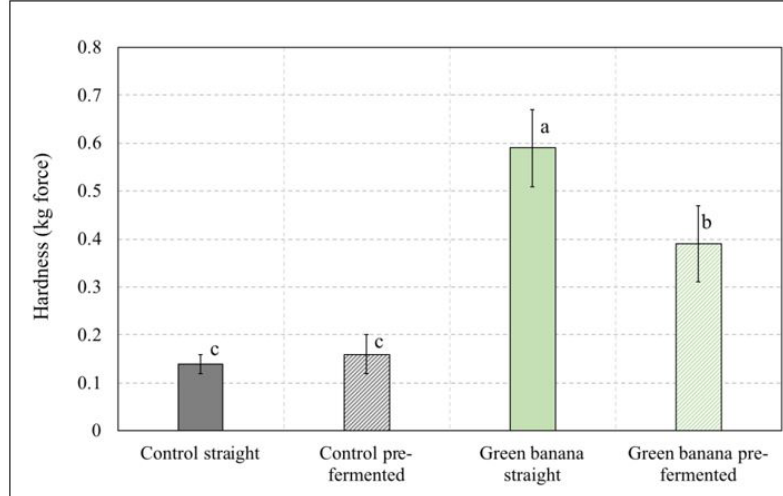

(a)

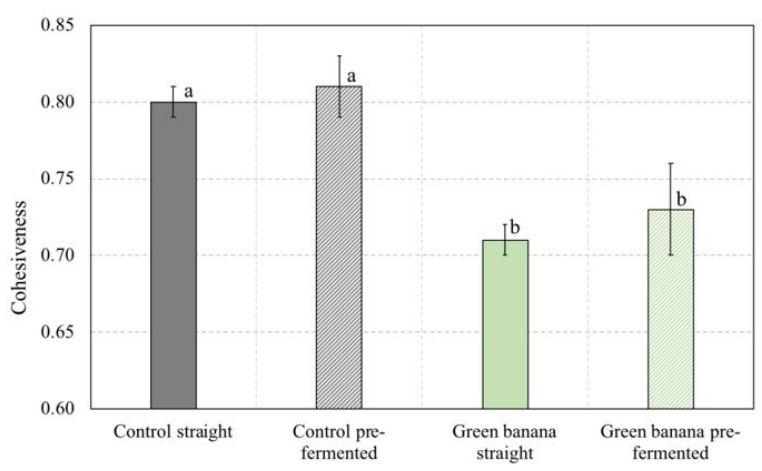

(c)

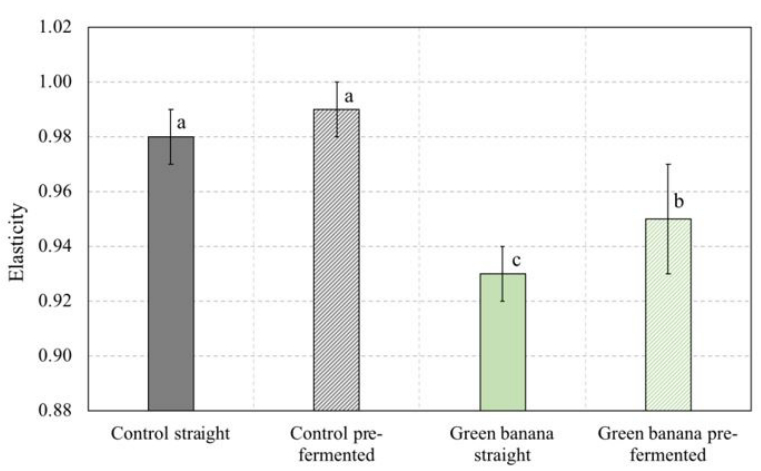

(b)

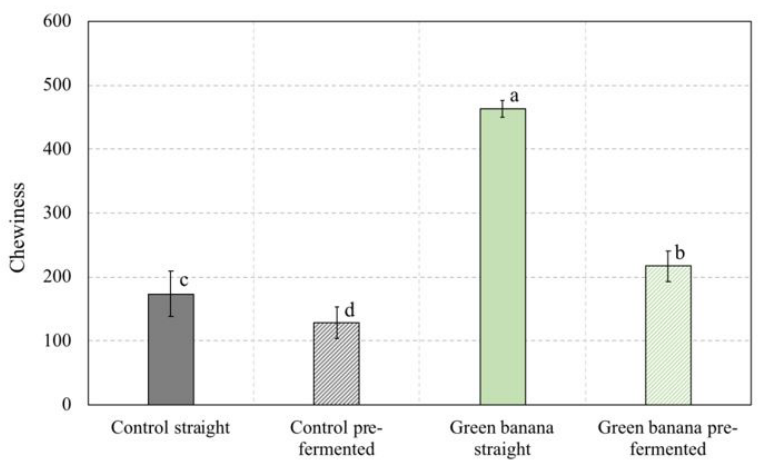

(d)

Figure 3. Crumb hardness (a), elasticity (b), cohesiveness (c) and chewiness (d) of control bread and green-banana-wheat breads produced by straight or pre-fermented dough method.

${ }^{\star}$ Different lower case letters in the same column indicate a significant difference $(\mathrm{p}<0.05)$ between the means for the different breads evaluated. 
At another hand, the texture profile analyses of greenbanana-wheat breads (GBWB) were significantly affect by dough method production. GBWB produced by pre-fermented method presented significantly reduced hardness in comparison to straight method (Figure 3a), making the values more near of control breads. Similar effect was reported for elasticity of GBWB (Figure 3b), higher values for pre-fermented breads, again approaching to the values of control breads. In general, similar effects were observed for cohesiveness (Figure3c) and chewiness (Figure 3d).

Bread produced by pre-fermented dough method have higher fermentation time, as well additional mixing, which bellow longer dough time hydration and gas cells redistribution, respectively. Both phenomes contribute to produce a final bread with a softer texture and finer porosity structure (Delcour \& Hoseney, 2010; Hayman et al., 1998). Besides, longer fermentation time could favorize $\mathrm{pH}$ reduction, which in tour enhanced protein solubility and therefore dough rheology, all of this favorizing dough structure development. This action supports breads with more porous, soft crumb, and finer grain when compared to straight dough method.

\section{Conclusion}

It could be verified that the use of pre-fermented dough method can represent an important strategy to be used for the development of composite bread. The results evidenced that GBWB produced by pre-fermented method had enhanced physical properties characteristics, being more near from those reported by WB.

Besides, the use of pre-fermented method must also be evaluated in relation to others aspects in special nutritional aspects, once longer fermentations times have been related to increase the levels of bioactive compounds, however more research is needed. In this way, the efficient of this method in bread production with low starch digestibility and, therefore, of low glycemic index, merits also be evaluated. Furthermore, the results evidenced in the present study represents a strategy to be more used in the development of composite wheat breads using different flours.

\section{Acknowledgements}

The authors wish to thank the São Paulo Research Foundation (FAPESP) for financial support (2013/12693-0; 2018/03324-5), Unified Scholarship Program (RUSP-USP) for R.O.L. fellowship.

\section{References}

Alcântara, R. G., Carvalho, R. A., \& Vanin, F. M. (2020a). Evaluation of wheat flour substitution type (corn, green banana and rice flour) and concentration on local dough properties during bread baking. Food Chemistry, 326, 126972. https://doi.org/10.1016/j. foodchem.2020.126972.

Alcântara, R. G., Fukumasu, H., Raspantini, P. C. F., Raspantini, L. E. R., Steel, C. J., Oliveira, L. C., Carvalho, R. A., \& Vanin, F. M. (2020b). Baking effect on resistant starch digestion from composite bread produced with partial wheat flour substitution. Journal of Food Quality, 2020, 1-13. http://dx.doi.org/10.1155/2020/9245035.
Amr, A., \& Ajo, R. (2005). Production of two types of pocket-forming flat bread by the sponge and dough method. Cereal Chemistry, 82(5), 499-503. http://dx.doi.org/10.1094/CC-82-0499.

Aziah, A. A. N., Ho, L. H., Noor Shazliana, A. A., \& Bhat, R. (2012). Quality evaluation of steamed wheat bread substituted with green banana flour. International Food Research Journal, 19(3), 869-876.

Baasandorj, T., Ohm, J. B., \& Simsek, S. (2020). Comparison of different experimental breadmaking methods and their associations with flour quality parameters in hard red spring wheat. Cereal Chemistry, 97(2), 515-526. http://dx.doi.org/10.1002/cche.10266.

Bárcenas, M. E., \& Rosell, C. M. (2006). Different approaches for improving the quality and extending the shelf life of the partially baked bread: low temperatures and HPMC addition. Journal of Food Engineering, 72(1), 92-99. http://dx.doi.org/10.1016/j. jfoodeng.2004.11.027.

Bárcenas, M. E., Benedito, C., \& Rosell, C. M. (2004). Use of hydrocolloids as bread improvers in interrupted baking process with frozen storage. Food Hydrocolloids, 18(5), 769-774. http://dx.doi.org/10.1016/j. foodhyd.2003.12.003.

Bredariol, P., Spatti, M., \& Vanin, F. M. (2019). Different baking conditions may produce breads with similar physical qualities but unique starch gelatinization behaviour. LWT, 111, 737-743. http:// dx.doi.org/10.1016/j.lwt.2019.05.094.

Carr, L. G., Rodas, M. A. B., Della Torre, J. C. M., \& Tadini, C. C. (2006). Physical, textural and sensory characteristics of 7-day frozen partbaked French bread. Lebensmittel-Wissenschaft + Technologie, 39(5), 540-547. http://dx.doi.org/10.1016/j.lwt.2005.03.012.

Crowley, P., Grau, H., \& Arendt, E. K. (2000). Influence of additives and mixing time on crumb grain characteristics of wheat bread. Cereal Chemistry, 77(3), 370-375. http://dx.doi.org/10.1094/ CCHEM.2000.77.3.370.

Datta, A. K., Sahin, S., Sumnu, G., \& Ozge Keskin, S. (2007). Porous media characterization of breads baked using novel heating modes. Journal of Food Engineering, 79(1), 106-116. http://dx.doi.org/10.1016/j. jfoodeng.2006.01.046.

Delcour, J. A., \& Hoseney, R. C. (2010). Yeast-leavened products. In AACC International Inc. (Ed.), Principles of cereal science and technology (3rd ed., pp. 151-177). Eagan, Minnesota: AACC International.

Faisant, N., Buléon, A., Colonna, P., Molis, C., Lartigue, S., Galmiche, J. P., \& Champ, M. (1995). Digestion of raw banana starch in the small intestine of healthy humans: structural features of resistant starch. The British Journal of Nutrition, 73(1), 111-123. http://dx.doi. org/10.1079/BJN19950013. PMid:7857906.

Gassenmeier, K., \& Schieberle, P. (1995). Potent aromatic compounds in the crumb of wheat bread (French-type) - influence of pre-ferments and studies on the formation of key odorants during dough processing. Zeitschrift fur Lebensmittel-Untersuchung und-Forschung, 201(3), 241-248. http://dx.doi.org/10.1007/BF01192996.

Gujral, H. S., \& Pathak, A. (2002). Effect of composite flours and additives on the texture of chapati. Journal of Food Engineering, 55(2), 173-179. http://dx.doi.org/10.1016/S0260-8774(02)00061-4.

Gularte, M. A., \& Rosell, C. M. (2011). Physicochemical properties and enzymatic hydrolysis of different starches in the presence of hydrocolloids. Carbohydrate Polymers, 85(1), 237-244. http://dx.doi. org/10.1016/j.carbpol.2011.02.025.

Hayman, D., Hoseney, R. C., \& Faubion, J. M. (1998). Bread crumb grain development during baking. Cereal Chemistry, 75(5), 577-580. http://dx.doi.org/10.1094/CCHEM.1998.75.5.577. 
Ho, L. H., Abdul Aziz, N. A., \& Azahari, B.. (2013). Physico-chemical characteristics and sensory evaluation of wheat bread partially substituted with banana (Musa acuminata X balbisiana cv. Awak) pseudo-stem flour. Food Chemistry, 139(1-4), 532-539. http://dx.doi. org/10.1016/j.foodchem.2013.01.039. PMid:23561142.

Ho, L.-H., Abdul Aziz, N. A., Bhat, R., \& Azahari, B. (2014). Storage studies of bread prepared by incorporation of the banana pseudostem flour and the composite breads containing hydrocolloids. CYTA: Journal of Food, 12(2), 141-149. http://dx.doi.org/10.1080/ 19476337.2013.806597.

Juarez-Garcia, E., Agama-Acevedo, E., Sayago-Ayerdi, S. G., Rodriguez-Ambriz, S. L., \& Bello-Pérez, L. A. (2006). Composition, digestibility and application in breadmaking of banana flour. Plant Foods for Human Nutrition (Dordrecht, Netherlands), 61(3), 131-137. http://dx.doi.org/10.1007/s11130-006-0020-x. PMid:17048100.

Katina, K., Arendt, E., Liukkonen, K. H., Autio, K., Flander, L., \& Poutanen, K. (2005). Potential of sourdough for healthier cereal products. Trends in Food Science \& Technology, 16(1-3), 104-112. http:// dx.doi.org/10.1016/j.tifs.2004.03.008.

López, A. C. B., Pereira, A. J. G., \& Junqueira, R. G. (2004). Flour mixture of rice flour, corn and cassava starch in the production of gluten-free white bread. Brazilian Archives of Biology and Technology, 47(1), 63-70. http://dx.doi.org/10.1590/S151689132004000100009 .

Özkaya, B., Baumgartner, B., \& Özkaya, H. (2018). Effects of concentrated and dephytinized wheat bran and rice bran addition on bread properties. Journal of Texture Studies, 49(1), 84-93. http://dx.doi. org/10.1111/jtxs.12286. PMid:28742221.

Poutanen, K., Flander, L., \& Katina, K. (2009). Sourdough and cereal fermentation in a nutritional perspective. Food Microbiology, 26(7), 693-699. http://dx.doi.org/10.1016/j.fm.2009.07.011. PMid:19747602.

Purlis, E. (2010). Browning development in bakery products - A review. Journal of Food Engineering, 99(3), 239-249. http://dx.doi. org/10.1016/j.jfoodeng.2010.03.008.
Purlis, E., \& Salvadori, V. O. (2007). Bread browning kinetics during baking. Journal of Food Engineering, 80(4), 1107-1115. http://dx.doi. org/10.1016/j.jfoodeng.2006.09.007.

Różyło, R. (2013). Determining the heterogeneity of wheat breadcrumb texture baked using two different methods: new application. International Journal of Food Properties, 16(1), 154-167. http:// dx.doi.org/10.1080/10942912.2010.535189.

Sciarini, L. S., Ribotta, P. D., León, A. E., \& Pérez, G. T. (2010). Effect of hydrocolloids on gluten-free batter properties and bread quality. International Journal of Food Science \& Technology, 45(11), 23062312. http://dx.doi.org/10.1111/j.1365-2621.2010.02407.x.

Shittu, T. A., Raji, A. O., \& Sanni, L. O. (2007). Bread from composite cassava-wheat flour: I. Effect of baking time and temperature on some physical properties of bread loaf. Food Research International, 40(2), 280-290. http://dx.doi.org/10.1016/j.foodres.2006.10.012.

Tribess, T. B., Hernández-Uribe, J. P., Méndez-Montealvo, M. G. C., Menezes, E. W., Bello-Perez, L. A., \& Tadini, C. C. (2009). Thermal properties and resistant starch content of green banana flour (Musa cavendishii) produced at different drying conditions. Lebensmittel-Wissenschaft + Technologie, 42(5), 1022-1025. http:// dx.doi.org/10.1016/j.lwt.2008.12.017.

Tuncel, N. B., Yilmaz, N., Kocabiyik, H., \& Uygur, A. (2014). The effect of infrared stabilized rice bran substitution on B vitamins, minerals and phytic acid content of pan breads: part II. Journal of Cereal Science, 59(2), 162-166. http://dx.doi.org/10.1016/j.jcs.2013.12.005.

Ureta, M. M., Diascorn, Y., Cambert, M., Flick, D., Salvadori, V. O., \& Lucas, T. (2018). Water transport during bread baking: impact of the baking temperature and the baking time. Food Science \& Technology International, 25(3), 187-197. http://dx.doi. org/10.1177/1082013218814144. PMid:30482042.

Wagner, M. J., Loubat, M., Sommier, A., Le Ray, D., Collewet, G., Broyart, B., Quintard, H., Davenel, A., Trystram, G., \& Lucas, T. (2008). MRI study of bread baking: experimental device and MRI signal analysis. International Journal of Food Science \& Technology, 43(6), 1129-1139. http://dx.doi.org/10.1111/j.1365-2621.2007.01633.x. 